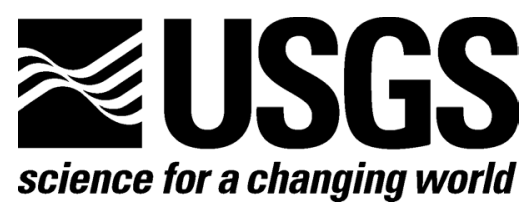

\title{
Preliminary vitrinite and bitumen reflectance, total organic carbon, and pyrolysis data for samples from Upper and Lower Cretaceous strata, Maverick Basin, south Texas
}

By Paul C. Hackley, Kristin O. Dennen, Rachel M. Gesserman, and Jennie L. Ridgley

Open-File Report 2009-1220 


\title{
U.S. Department of the Interior \\ KEN SALAZAR, Secretary
}

U.S. Geological Survey
Suzette M. Kimball, Acting Director

\author{
U.S. Geological Survey, Reston, Virginia: 2009
}

For more information on the USGS - the Federal source for science about the Earth, its natural and living resources, natural hazards, and the environment, visit http://www.usgs.gov or call 1-888-ASK-USGS

For an overview of USGS information products, including maps, imagery, and publications, visit http://www.usgs.gov/pubprod

To order this and other USGS information products, visit http://store.usgs.gov

Any use of trade, product, or firm names is for descriptive purposes only and does not imply endorsement by the U.S. Government.

\section{Suggested citation:}

Hackley, P.C., Dennen, K.O., Gesserman, R.M., and Ridgley, J.L., 2009, Preliminary vitrinite and bitumen reflectance, total organic carbon, and pyrolysis data for samples from Upper and Lower Cretaceous strata, Maverick Basin, south Texas: U.S. Geological Survey Open-File Report 2009-1220, 3 p., 1 table, available only online at http://pubs.usgs.gov/of/2009/1220/. 


\section{Contents}

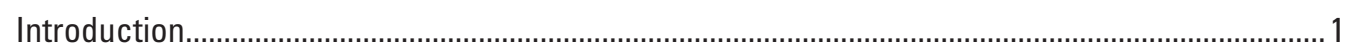

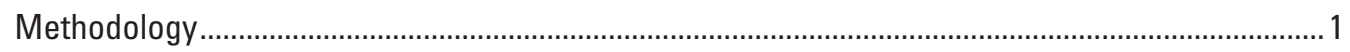

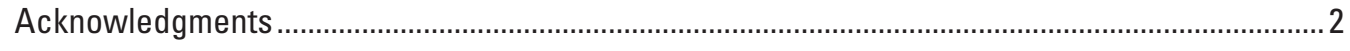

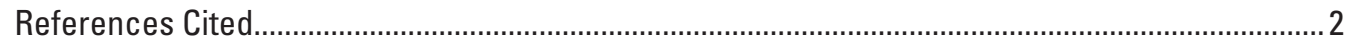

\section{Table}

1. Preliminary vitrinite and bitumen reflectance, TOC, and pyrolysis data for Upper and Lower Cretaceous age samples from the Maverick Basin, south Texas ..................................................................................... 


\title{
Preliminary vitrinite and bitumen reflectance, total organic carbon, and pyrolysis data for samples from Upper and Lower Cretaceous strata, Maverick Basin, south Texas
}

\author{
By Paul C. Hackley, Kristin O. Dennen, Rachel M. Gesserman, and Jennie L. Ridgley
}

\section{Introduction}

The Lower Cretaceous Pearsall Formation, a regionally occurring limestone and shale interval of 500-600-ft maximum thickness (Rose, 1986), is being evaluated as part of an ongoing U.S. Geological Survey (USGS) assessment of undiscovered hydrocarbon resources in onshore Lower Cretaceous strata of the northern Gulf of Mexico.

The purpose of this report is to release preliminary vitrinite and bitumen reflectance, total organic carbon, and pyrolysis data for Pearsall Formation, Glen Rose Formation, Hosston Formation, Austin Group, and Eagle Ford Group samples from the Maverick Basin in south Texas in order to aid in the characterization of these strata in this area. The preliminary nature of this report and the data contained herein reflect that the assessment and characterization of these samples is a work currently in progress.

Pearsall Formation subdivisions are, in ascending stratigraphic order, the Pine Island Shale, James Limestone, and Bexar Shale Members (Loucks, 2002). The Lower Cretaceous Glen Rose Formation is also part of the USGS Lower Cretaceous assessment and produces oil in the Maverick Basin (Loucks and Kerans, 2003). The Hosston Formation was assessed by the USGS for undiscovered oil and gas resources in 2006 (Dyman and Condon, 2006), but not in south Texas.

The Upper Cretaceous Austin Group is being assessed as part of the USGS assessment of undiscovered hydrocarbon resources in the Upper Cretaceous strata of the northern Gulf of Mexico and, along with the Upper Cretaceous Eagle Ford Group, is considered to be an important source rock in the Smackover-Austin-Eagleford Total Petroleum System (Condon and Dyman, 2006). Both the Austin Group and the Eagle Ford Group are present in the Maverick Basin in south Texas (Rose, 1986).

\section{Methodology}

Spontaneous potential-resistivity logs for 26 conventional wells in the Maverick basin were evaluated to correlate the stratigraphic positions of the Pearsall Formation, Glen Rose Formation, Hosston Formation, Austin Group, and Eagle Ford Group. Cuttings and core available from the Texas Bureau of Economic Geology for these wells were sampled and prepared for petrographic, geochemical, and other analyses. For comparison purposes, samples were also collected from Pearsall equivalent outcrops in western Travis County, Texas, on the San Marcos Arch (the Pearsall Formation does not outcrop in the Maverick Basin).

Samples were prepared and analyzed for reflectance at the USGS according to the protocols outlined on the USGS Organic Petrology Laboratory Web page at http://energy.er.usgs.gov/coal_studies/organic_petrology/laboratory.html. Samples were analyzed for total organic carbon and programmed pyrolysis by Weatherford Laboratories according to standard analytical procedures. Preliminary vitrinite reflectance, TOC, and pyrolysis data are compiled in table 1. 


\section{Description of Data for Table 1}

A table containing variable headings and explanations for table 1 appears below.

Table 1. Preliminary vitrinite and bitumen reflectance, TOC, and pyrolysis data for Upper and Lower Cretaceous age samples from the Maverick Basin, south Texas.

\begin{tabular}{|c|c|}
\hline Variable Heading & Description or Explanation \\
\hline API Number & $\begin{array}{l}\text { A unique number that identifies a well site and cores taken from that well in public well records. It } \\
\text { specifies the State, the county or parish, and a permit number for the well issued by the State in } \\
\text { which the well is drilled. The API numbers for the wells in this report are publicly available from the } \\
\text { Texas Bureau of Economic Geology. }\end{array}$ \\
\hline Lease/Well Name & $\begin{array}{l}\text { Most wells are named for the person leasing or owning the land where the well is drilled. If multiple } \\
\text { holes are drilled on a property, the name is usually followed by a number. }\end{array}$ \\
\hline Formation or Member & Geologic name of formation or member from which sample was taken. \\
\hline Top Depth (ft) & Minimum depth of core interval from which sample was taken. \\
\hline Bottom Depth (ft) & Maximum depth of core interval from which sample was taken. \\
\hline Sample Type & $\begin{array}{l}\text { Core indicates that samples were taken directly from the core. Cuttings are pieces of material brought } \\
\text { up from the well during drilling. }\end{array}$ \\
\hline $\mathrm{S}_{3}$ & $\mathrm{mg} \mathrm{CO} / \mathrm{g}$ of sample released between 300 and $390^{\circ} \mathrm{C}$ \\
\hline $\mathrm{T}_{\text {MAX }}$ & Temperature from pyrolysis analysis corresponding to maximum $\mathrm{S}_{2}$ production in ${ }^{\circ} \mathrm{C}$. \\
\hline Calculated $\%$ RO & Calculated $\mathrm{R}_{\mathrm{o}}=0.0180 \times \mathrm{T}_{\max }-7.16$ (Jarvie and others, 2001) \\
\hline Measured \%RO & Mean value of percent reflectance measurements of vitrinite and (or) bitumen in oil (ASTM, 2008). \\
\hline HI & Hydrogen index $=\mathrm{mg} \mathrm{S}_{2} / \mathrm{g}$ TOC x 100 \\
\hline OI & Oxygen index $=\mathrm{mg} \mathrm{S}_{3} / \mathrm{g}$ TOC x 100 \\
\hline PI & Production index $=\mathrm{S}_{1} / \mathrm{S}_{1}+\mathrm{S}_{2}$ \\
\hline n.d. & $\begin{array}{l}\text { No data. Either the analytical laboratory reporting the results did not provide this information, or in the } \\
\text { case of measured } \% \mathrm{R}_{\mathrm{o}} \text {, the analyses are ongoing, reflecting the preliminary nature of this report. } \% \mathrm{R}_{\mathrm{o}} \\
\text { data for these samples will be provided in later reports. }\end{array}$ \\
\hline
\end{tabular}

\section{Acknowledgments}

James Donnelly of the Texas Bureau of Economic Geology coordinated shipment of Pearsall core and cuttings samples to the USGS. Timely, but thorough, reviews from Mark J. Pawlewicz and John SanFilipo of the USGS greatly improved this report.

\section{References Cited}

ASTM, 2008, Annual book of ASTM standards: Petroleum products, lubricants, and fossil fuels; gaseous fuels; coal and coke, sec. 5, v. 5.06: ASTM International, West Conshohocken, Pa., 720 p.
Condon, S.M., and Dyman, T.S., 2006, 2003 geologic assessment of undiscovered conventional oil and gas resources in the Upper Cretaceous Navarro and Taylor Groups, Western Gulf Province, Texas: U.S. Geological Survey Digital Data Series DDS-69-H, chap. 2, 42 p.

Dyman, T.S., and Condon, S.M., 2006, Assessment of undiscovered conventional oil and gas resources-Lower Cretaceous Travis Peak and Hosston Formations, Jurassic Smackover Interior Salt Basins Total Petroleum System, in the East Texas Basin and Louisiana-Mississippi Salt Basins Provinces: U.S. Geological Survey Digital Data Series DDS-69-E, chap. 5, 39 p.

Jarvie, D.M., Morelos, A., and Han, Z., 2001, Detection of pay zones and pay quality, Gulf of Mexico: Application of geochemical techniques: Gulf Coast Association of Geological Societies Transactions, v. 51, p. 151-160. 
Loucks, R.G., 2002, Controls on reservoir quality in platforminterior limestones around the Gulf of Mexico: example from the Lower Cretaceous Pearsall Formation in South Texas: Gulf Coast Association of Geological Societies Transactions, v. 52, p. 659-672.

Loucks, R.G., and Kerans, C., 2003, Lower cretaceous Glen Rose "patch reef" reservoir in the Chittim field, Maverick County, south Texas: Gulf Coast Association of Geological Societies Transactions, v. 53, p. 490-503.
Rose, Peter, 1986, Oil and gas occurrence in Lower Cretaceous rocks, Maverick Basin area, southwest Texas, in Stapp, W. L., ed., Contributions to the geology of South Texas 1986: South Texas Geological Society, San Antonio, Texas, $14 \mathrm{p}$. 